\title{
Cultural Performances in Medieval France, Essays in Honor of Nancy Freeman Regalado, Edited by Eglal Doss-Quinby, Roberta L. Krueger, E. Jane Burns
}

\section{G. Matteo Roccati}

\section{CpenEdition}

1 Journals

\section{Édition électronique}

URL : http://journals.openedition.org/studifrancesi/6541

DOI : ERREUR PDO dans /localdata/www-bin/Core/Core/Db/Db.class.php L.34 : SQLSTATE[HY000]

[2006] MySQL server has gone away

ISSN : 2427-5856

\section{Éditeur}

Rosenberg \& Sellier

\section{Édition imprimée}

Date de publication : 1 septembre 2010

Pagination : 337-338

ISSN : 0039-2944

\section{Référence électronique}

G. Matteo Roccati, «Cultural Performances in Medieval France, Essays in Honor of Nancy Freeman Regalado, Edited by Eglal Doss-Quinby, Roberta L. Krueger, E. Jane Burns », Studi Francesi [En ligne], 161 (LIV | II) | 2010, mis en ligne le 30 novembre 2015, consulté le 07 janvier 2021. URL : http:// journals.openedition.org/studifrancesi/6541; DOI : https://doi.org/10.4000/studifrancesi.6541

Ce document a été généré automatiquement le 7 janvier 2021.

\section{(†)

Studi Francesi è distribuita con Licenza Creative Commons Attribuzione - Non commerciale - Non opere derivate 4.0 Internazionale. 


\title{
Cultural Performances in Medieval France, Essays in Honor of Nancy Freeman Regalado, Edited by Eglal Doss-Quinby, Roberta L. Krueger, E. Jane Burns
}

\author{
G. Matteo Roccati
}

\section{RÉFÉRENCE}

Cultural Performances in Medieval France, Essays in Honor of Nancy Freeman Regalado, Edited by Eglal DOSS QUINBY, Roberta L. KRUEGER, E. Jane BURNS, Cambridge, D.S. Brewer («Gallica», 5), 2007, pp. XXXVI-302.

1 L'ouvrage rassemble vingt-quatre contributions et est organisé en cinq parties. On trouvera dans la première («Poetic and Musical Performances»): Michel zINK, La poésie comme récit (pp. 3-13; considérations sur la conception médiévale de la poésie); Samuel N. ROSENBERG, Colin Muset and Performance (pp. 15-23); Edward H. ROESNER, "Subtilitas" and "Delectatio": «Ne m'a pas oublié» (pp. 25-43; sur le motet Ne m'a pas oublié / In seculum, ms. Montpellier H 196, f. 246); Jane H. M. TAYLOR, "Flables couvertes": Poetry and Performance in the Fifteenth Century (pp. 45-53; fine étude d'un passage du Pastoralet mettant en scène une compétition poétique, étude qui explicite bien la nature et les enjeux des compétences requises aux poètes "amateurs").

2 La deuxième section («Performing Sexual and Social Identities») rassemble les études suivantes: Mark CRUSE, Intimate Performance: An Ivory Writing Tablet Cover at The Cloisters, (pp. 57-69; sur deux petites plaques représentant des scènes courtoises); E. Jane BURNS, A Cultural Performance in Silk: Sebelinne's "aumousniere» in the "Dit de l'Empereur Constant" (pp. 71-78; sur la signification de l'aumonière, opposée à bourse, dans ce dit du XIII s. 
d'argument byzantin); Kimberlee CAMPBELL, Acting Like a Man: Performing Gender in “Tristan de Nanteuil" (pp. 79-89; sur l'inversion des rôles - couardise, travestissements dans cette chanson de geste du XIV s.); Sylvia HUOT, Amorous Performances: The "Aventure de l'espee vermeille» in "Perceforest"(pp. 91-98; sur cet épisode du livre V, réaffirmation de la norme sexuelle de la chevalerie); Ardis BUTTERFIELD, Historicizing Performance: The Case of the "Jeu de Robin et Marion" (pp. 99-107; sur les nombreux «displacements - social, sexual, linguistic, musical, generic» (p. 106) dans le texte, que l'A. met en relation avec Naples angévine des années 1280); Marilyn LAWRENCE, The Protean Performer: Defining Minstrel Identity in Tristan Narratives (pp. 109-119; sur la figure du “minstrel” telle qu'elle est présentée dans la Folie d'Oxford et dans l'épisode de «Tristan ménestrel» dans la Continuation de Perceval de Gerbert de Montreuil).

3 Les contributions de la troisième section traitent de la relation entre «Devotional Practice and Textual Performance»: Kathryn A. DUYS, Performing Vernacular Song in Monastic Culture: The "lectio divina" in Gautier de Coinci's "Miracles de Nostre Dame" (pp. 123-133); Robert L. A. CLARK and Pamela SHEINGORN, Performative Reading: Experiencing through the Poet's Body in Guillaume de Digulleville's "Pèlerinage de Jhesucrist" (pp. 135-151); LUCY FREEMAN SANDLER, The Anglo-Norman Office of the Cross in the Lichtenthal Psalter (pp. 153-162; sur les lettrines historiées de l'office, caractéristiques de l'enluminure anglaise de la deuxième moitié du XIV ${ }^{e}$ s., illustrant le cycle de la Passion); Elizabeth A. R. BROWN, «Laver de ses pechiés une pecheresse royale»: Psalm Collects in an Early Fourteenth-Century Devotional Book (pp. 163-177; sur le ms. New York Public Library, Spencer 56, exécuté à l'intention de Blanche de Bourgogne, épouse de Charles IV, accusée d'adultère).

4 La quatrième section, "Persuasive Performances», rassemble les études de Renate BLUMENFELD-KOSINSKI, Dramatic Troubles of "Ecclesia": Gendered Performances of the Divided Church (pp. 181-194; sur la figure allégorique féminine de l'Eglise en proie au schisme chez Rupert de Deutz, Gautier de Chatillon, Eustache Deschamps, Honoré Bovet); Laurie PostlewATE, Preaching the Sins of the Ladies: Nicole Bozon's “Char d'Orgueil" (pp. 195-202); Helen SOLTERER, Making Names, Breaking Lives: Women and Injurions Language at the Court of Isabeau of Bavaria and Charles VI (pp. 203-217; à propos des damoiselles d'honneur); Doris J. WALTER, Performing the Nation: The Play Performed at the Great Feast in Christine de Pizan's Biography of Charles V (pp. 219-232; sur le sens du récit de la visite de l'empereur Charles IV à Paris en 1378).

Dans la cinquième section, «Re-Enactments and Legacies», on notera: Evelyn BIRGE VITZ, Variegated Performance of "Aucassin et Nicolette" (pp. 235-245); Kathleen A. LOYSEN, Medieval Representations of Storytelling and Story-Performance (pp. 247-253; sur la mise en scène de l'acte de raconter dans les Cent nouvelles nouvelles et les Evangiles des quénouilles); Cynthia J. BRown, Paratextual Performances in the Early Parisian Book Trade: Antoine Vérard's Edition of Boccaccio's "Nobles et cleres dames" (1493) (pp. 255-264); Elizabeth EMERY, 'Resuscitating' Medieval Literature in New York and Paris: "La femme que Nostre-Dame garda d'estre arse" at Yvette Guilbert's School of Theatre, 1919-24 (pp. 265-278; représentation tirée des Miracles de Nostre-Dame par personnages); Anne AZEMA, «Dunc chante haut et cler»: remarques sur l'interprétation de la musique médiévale (pp. 289-299). 